\title{
Tracking bubble evolution inside a silicic dike
}

DOI:

10.1016/j.lithos.2016.08.012

\section{Document Version}

Accepted author manuscript

Link to publication record in Manchester Research Explorer

\section{Citation for published version (APA):}

Álvarez-Valero, A. M., Okumura, S., Arzilli, F., Borrajo, J., Recio, C., Ban, M., Gonzalo, J. C., Benítez, J. M., Douglas, M., Sasaki, O., Franco, P., Gómez-Barreiro, J., \& Carnicero, A. (2016). Tracking bubble evolution inside a silicic dike. Lithos, 262, 668-676. https://doi.org/10.1016/j.lithos.2016.08.012

\section{Published in:}

Lithos

\section{Citing this paper}

Please note that where the full-text provided on Manchester Research Explorer is the Author Accepted Manuscript or Proof version this may differ from the final Published version. If citing, it is advised that you check and use the publisher's definitive version.

\section{General rights}

Copyright and moral rights for the publications made accessible in the Research Explorer are retained by the authors and/or other copyright owners and it is a condition of accessing publications that users recognise and abide by the legal requirements associated with these rights.

\section{Takedown policy}

If you believe that this document breaches copyright please refer to the University of Manchester's Takedown Procedures [http://man.ac.uk/04Y6Bo] or contact uml.scholarlycommunications@manchester.ac.uk providing relevant details, so we can investigate your claim.

\section{OPEN ACCESS}


Elsevier Editorial system(tm) for Lithos Manuscript Draft

Manuscript Number: LITHOS5319R2

Title: Tracking bubble evolution inside a silicic dike

Article Type: Regular Article

Keywords: Volcanic bubbles; Dacite; X-ray micro-tomography; Crustal xenoliths; Conduit depths; Stable Isotopes

Corresponding Author: Dr. Antonio M. Álvarez-Valero,

Corresponding Author's Institution: Universidad de Salamanca

First Author: Antonio M. Álvarez-Valero

Order of Authors: Antonio M. Álvarez-Valero; Satoshi Okumura; Fabio Arzilli; Javier Borrajo; Clemente Recio; Masao Ban; Juan Carlos Gonzalo; Jose Benítez; Madison Douglas; Osamu Sasaki; Piedad Franco; Juan GómezBarreiro; Asunción Carnicero

Abstract: Pressure estimates from rapidly erupted crustal xenoliths constrain the depth of intrusion of the silicic lavas hosting them. This represents an opportunity for tracking magmatic bubble's evolution and quantifying the variation in bubble volume during rapid magma ascent through a volcanic dike just prior to eruption. The petrology, stableisotope geochemistry and X-ray micro-tomography of dacites containing crustal xenoliths, erupted from a Neogene volcano in SE Spain, showed an increase in porosity from $\sim 1.7$ to 6.4 from $\sim 19$ to $13 \mathrm{~km}$ depth, at nearly constant groundmass and crystal volumes. This result provides additional constraints for experimental and numerical simulations of subvolcanic magma-crust degassing processes in silicic systems, and may allow the characterization of volcanic eruptive styles based on volatile content. 
Direct observation of bubbles in a natural-silicic volcano-laboratory

Combination of petrology, geochemistry and micro-computed-tomography

Bubbles evolution in the magma dike from 19 to $13 \mathrm{~km}$ depth

Implications for the volatiles influence in the eruptive processes at higher depths than the usually considered for the volcanic vent 


\section{Tracking bubble evolution inside a silicic dike}

2

3 Antonio M. Álvarez-Valero ${ }^{1^{*}}$, Satoshi Okumura ${ }^{2}$, Fabio Arzilli ${ }^{3}$, Javier

4 Borrajo $^{4}$, Clemente Recio ${ }^{1}$, Masao Ban ${ }^{5}$, Juan C. Gonzalo ${ }^{1}$, José M. Benítez ${ }^{1}$,

5 Madison Douglas ${ }^{6}$, Osamu Sasaki $^{7}$, Piedad Franco $^{1}$, Juan Gómez-Barreiro $^{1}$,

6 Asunción Carnicero ${ }^{1}$

7

$8{ }^{1}$ Department of Geology, Faculty of Sciences, University of Salamanca, Spain

9 ( ${ }^{*}$ corresponding author: aav@usal.es)

$10{ }^{2}$ Division of Earth and Planetary Materials Science, Department of Earth Science,

11 Graduate School of Science, Tohoku University, Sendai, Miyagi, Japan

$12{ }^{3}$ School of Earth, Atmospheric and Environmental Sciences,

13 University of Manchester, $U K$

$14{ }^{4}$ Department of Physics, Engineering and Medical Radiology, University of

15 Salamanca, Spain

$16{ }^{5}$ Department of Earth and Environmental Sciences, Yamagata University, Japan

$17{ }^{6}$ Department of Earth, Atmospheric and Planetary Sciences, MIT, Cambridge, MA,

18 USA

$19{ }^{7}$ Division of GeoEnvironmental Science, Department of Earth Science, Graduate

20 School of Science, Tohoku University, Sendai, Miyagi, Japan 


\section{ABSTRACT}

27 Pressure estimates from rapidly erupted crustal xenoliths constrain the depth of

28 intrusion of the silicic lavas hosting them. This represents an opportunity for tracking

29 magmatic bubble's evolution and quantifying the variation in bubble volume during

30 rapid magma ascent through a volcanic dike just prior to eruption. The petrology,

31 stable-isotope geochemistry and X-ray micro-tomography of dacites containing

32 crustal xenoliths, erupted from a Neogene volcano in SE Spain, showed an increase

33 in porosity from $\sim 1.7$ to $6.4 \%$ from $\sim 19$ to $13 \mathrm{~km}$ depth, at nearly constant

34 groundmass and crystal volumes. This result provides additional constraints for

35 experimental and numerical simulations of subvolcanic magma-crust degassing

36 processes in silicic systems, and may allow the characterization of volcanic eruptive

37 styles based on volatile content.

39 Keywords: Volcanic bubbles; Dacite; X-ray micro-tomography; Crustal xenoliths;

40 Conduit depths; Stable Isotopes

41

42

43 


\section{1. Introduction}

52 Processes occurring in the conduit between a magma chamber and the surface

53 may trigger an eruption or alter the characteristics of one already in progress (e.g.

54 Costa et al., 2007; 2009). In this regard, gases and fluids play a crucial. The

55 understanding of how gases behave and influence the eruptive style of volcanoes is

56 mainly based on observations of volcanic products, numerical models, and laboratory

57 experiments (e.g., Eichelberger et al., 1986; Jaupart and Allègre, 1991; Woods and

58 Koyaguchi, 1994; Klug and Cashman, 1996; Okumura et al., 2009; Fiege et al.,

59 2014; Fiege and Cichy, 2015). However, the evolution of magmatic gases and fluids

60 immediately prior to eruption is difficult to understand due to the complexity of

61 observing magmatic activity below the surface. While shallower volcanic vents have

62 been investigated through the analysis and experimental reproduction of pyroclastic

63 products (e.g., Valentine, 2012), interactions between the crust and magma at depth

64 (from c. 4 to $20 \mathrm{~km}$ ) require further investigation (e.g., Álvarez-Valero et al., 2015;

65 Pla and Álvarez-Valero, 2015). The distribution, size, quantity and morphology of

66 bubbles in acidic magmas prior to eruption is under active research (e.g., Wallace et

67 al., 1995; Gualda and Anderson, 2007; Baker et al., 2012). In particular, a better

68 understanding of bubble behavior at depths greater than $2 \mathrm{~km}$ is required in order to

69 constrain the influence of magmatic buoyancy and magma chamber overpressure in

70 driving eruptions (e.g., Malfait et al., 2014), as well as the depth at which melt-gas

71 separation starts via bubble nucleation. The occurrence and dynamics of explosive

72 eruptions mainly depend on the initial volatile content of the magma, the ability of

73 gases to escape during its ascent, the viscosity as proxy for diffusivity of volatile

74 species, solubility vs. composition, and pressure. In order to advance in these

75 aspects, we examine El Hoyazo volcano (a Neogene silicic lava dome in SE Spain) 
76 with the aim of finding out: (i) when and where bubbles nucleated under the volcano,

77 and (ii) how the porosity varies along the dike as a function of depth. We explored

78 how magmatic bubbles and volatiles evolve during rapid ascent, and their relations to

79 eruptive potential by integrating (i) visual analysis of dacitic samples using SEM and

80 X-ray micro-computed-tomography (micro-CT) (e.g., Gualda and Rivers, 2006;

81 Polacci et al., 2006; Baker et al., 2012); (ii) petrologic depth estimates of the crustal

82 xenoliths and (iii) stable isotope ratios in xenoliths and dacites, to constrain the open

83 vs. closed nature of the system at the depth within the dike where dacite magma and

84 xenoliths came into contact. We then utilized the magmatic porosities and depths to

85 derive a rate of bubble formation during magma ascent towards eruption at El

86 Hoyazo.

87

88 1.1. Previous petrological and geochemical results for partially melted crustal

89 xenoliths and their host dacites

90 The Neogene Volcanic Province (NVP) of SE Spain (Fig. 1) contains high-K

91 calc-alkaline and shoshonitic lava series, which are peraluminous. Lithologically

92 these are largelly calc-alkaline dacites rich in $\mathrm{K}_{2} \mathrm{O}$, with volatile contents from 2 to 4

93 wt\% (mainly $\mathrm{H}_{2} \mathrm{O}, \mathrm{CO}_{2}$ ) (Zeck, 1970; Benito et al., 1999). These dacites host crustal

94 xenoliths -mainly medium to coarse-grained granulite-facies rocks- with a restitic

95 bulk composition depleted in silica and enriched in aluminium and iron (Zeck, 1970;

96 Cesare et al., 1997; Benito et al., 1999; Duggen et al., 2004). The xenoliths were

97 quenched immediately after eruption (e.g., Zeck, 1970; Cesare et al., 1997; Álvarez-

98 Valero and Waters, 2010), so their microstructures provide a snapshot of the

99 anatectic conditions at depth (e.g., Zeck, 1970; Cesare et al., 1997; Álvarez-Valero

100 and Kriegsman, 2007). El Hoyazo (Fig. 1) was a submarine lava dome with a 500 
$101 \mathrm{~m}$ crater radius, and is overlain by Miocene reef carbonates. It is a small circular

102 outcrop of c. $0.7 \mathrm{~km}^{2}$, which dacites include up to $15 \%$ in volume of crustal material

103 (Zeck, 1970). Its atoll geomorphology shows an inner depressed part of mainly

104 dacitic material that corresponds to the old volcanic cone, whereas the top relief is

105 composed by the reef carbonates formed onto the volcanics, which host the crustal

106 xenoliths. Crustal xenoliths and their host dacites are ramdonly collected within the

107 inner part.

108 The mineralogical and chemical features of the dacite hosting the xenoliths are

109 described, among others, by Zeck (1970) and Benito et al. (1999). The dacite is

110 porphyritic, with $>50$ vol. $\%$ of rhyolitic glassy matrix (both fresh and devitrified),

111 and phenocrysts of mainly plagioclase, biotite, cordierite, and minor orthopyroxene,

112 amphibole, magnetite and ilmenite. Xenocrysts of garnet and quartz are locally

113 present. The xenoliths relevant for this study, i.e. those from the deepest zone

114 detected, are texturally dominated by coarse-grained biotite, elliptical garnet, and

115 large foliated mats of fibrolitic sillimanite, that is locally overprinted by spinel

116 crystals rimmed by melt and minor cordierite. Glass is partially recrystallized to

117 plagioclase, K-feldspar and thin laths of high-Ti biotite. The microtexture of

118 the fibrolitic matrix has a relatively high proportion of glass, and is rimmed by glass

119 against other phases. Spinel porphyroblasts are idioblastic and zoned, both texturally

120 and compositionally (see also Álvarez-Valero and Kriegsman, 2007; Álvarez-Valero

121 and Waters, 2010). The shallowest xenoliths are of the Spl-Crd-M type. The garnet is

122 surrounded by coronas, and the overall parageniesis is Spl-Crd-Pl-Kfs-M.

123 The coronas mimic the outline of the previous garnet, whose breakdown reaction has

124 been described in detail by Álvarez-Valero et al. (2007). Sillimanite occurs as

125 aggregates of fine needles (fibrolite) in the glass. 
126 Glass mostly occurs as inclusions in garnet and plagioclase, and as microveins

127 of devitrified material, as well as intergrown with fibrolite. Melt inclusions exhibit

128 either rounded or regular, negative-crystal shapes. As outlined by Cesare et al.

129 (1997), their textural position within host phases is compatible with a

130 primary trapping (Roedder 1984). Glass is transparent, showing no evidence for

131 devitrification or crystallization. The bubbles are essentially empty, shrinkage

132 bubbles, with no detectable Raman-active components. Fluid inclusions are rare and

133 restricted to biotite-poor xenoliths. These inclusions contain $\mathrm{CO}_{2}$-dominated fluids

134 (Cesare et al., 2004).

135 Direct evidence of partial melting and melt extraction in the xenoliths is provided by

136 the occurrence and high abundance of fresh glass (quenched melt), which occurs as

137 an interstitial phase in layer-parallel films of the matrix and as both devitrified and

138 fresh pockets (Zeck, 1970; Cesare et al., 1997). Glass is also enclosed by all

139 minerals, indicating that all minerals crystallized in the presence of a melt phase,

140 i.e., during partial melting. The presence of intergranular melt films suggest that melt

141 was present during grain growth (by incongruent melting reactions), during

142 subsequent (re)crystallization steps, and after recrystallization of restitic phases had

143 ceased. Melt in inclusions and intergranular films of xenoliths is chemically different

144 from the glass of the dacite host, which has lower $\mathrm{Al} / \mathrm{Si}$ and higher $\mathrm{K} / \mathrm{Na}$ ratios

145 (Cesare et al., 1997). Based on mass balance calculations between melt inclusions,

146 xenoliths and potential metapelitic sources, a high degree (35-60 wt \%) of

147 melt extraction has been estimated at El Hoyazo (Cesare et al., 1997).

148 Numerous isotopic studies have demonstrated that mafic magmas that formed in

149 the mantle or lower crust interact with felsic mid-crustal magmas and country rock to

150 produce so-called hybrid magmas (e.g., Benito et al., 1999; Duggen et al., 2004; 
151 Leeman et al., 2008). The NVP dacites are the result of mixing between rhyolites

152 extracted from partially melted pelitic crust and basalts derived from mafic

153 underplating of the Betic Cordillera (e.g., Benito et al., 1999; Duggen et al., 2004;

154 Álvarez-Valero and Kriegsman, 2007).

155 Microstructures and age relationships in the xenoliths indicate that they first

156 underwent a stage of migmatization and melt extraction, where the rhyolite mixed

157 with the primary basalt to form the host dacites (Duggen et al., 2004; Álvarez-Valero

158 and Kriegsman, 2007). A second sequence of melt-bearing reaction microstructures,

159 developed in a transiently heated wall-rock profile adjacent to the magma conduit,

160 triggered the collapse of the crustal container walls resulting in the brief residence of

161 xenoliths in a dacitic magma at c. $850^{\circ} \mathrm{C}$ (Álvarez-Valero and Waters, 2010). The

162 xenoliths experienced rapid transfer from depth to the surface during the eruption,

163 with minutes to hours separating the xenoliths partial melting and their preservation

164 by post-eruptive quenching (Álvarez-Valero and Waters, 2010; Álvarez-Valero et al.,

165 2015; Pla and Álvarez-Valero, 2015).

\section{2. Methods}

168 The provenance depths of the crustal xenoliths below El Hoyazo are well

169 constrained at c. 6 and 4.5 Kbar through thermodynamic modeling (i.e. 19 and 13

170 km depth, respectively; Table 1; see also Álvarez-Valero and Waters, 2010 for

171 details of the pressure estimates). These depths define a precise section of the

172 volcanic dike. Hence, in order to track the bubbles evolution at depth along the dike,

173 we selected twelve dacites from within few centimetres of a hosted xenolith that

174 quenched simultaneously. In other words, these dacites host a variety of crustal

175 xenoliths, which served as samples of restite from various known depths (Álvarez- 
176 Valero and Waters, 2010) under El Hoyazo volcano (Table 1; Fig. 1). They were

177 analyzed for the stable isotope ratios of hydrogen and oxygen $\left(\delta \mathrm{D}, \delta^{18} \mathrm{O}\right)$. Four of

178 them were selected for X-ray micro-Computed Tomography (micro-CT) and

179 Scanning Electron Microscope (SEM) analysis (samples HY-14-2; HY-14-8; HY-14-

180 9; HY-14-10). Location coordinates are not useful in this studied case as the

181 xenoliths occur randomly distributed within the entire outcrop.

182

183 2.1. Stable Isotope Analysis

184 Oxygen isotope analyses of dacites and xenoliths, as well as single xenocrysts, were

185 done at the Servicio General de Analisis de Isotopos Estables, University of

186 Salamanca, Spain, on whole-rock powders by laser fluorination (Clayton and

187 Mayeda, 1963), employing a Synrad $25 \mathrm{~W} \mathrm{CO}_{2}$ laser (Sharp, 1990) and $\mathrm{ClF}_{3}$ as

188 reagent (e.g., Borthwick and Harmon, 1982). Isotope ratios were measured on a VG-

189 Isotech SIRA-II dual-inlet mass spectrometer. Both internal and international

190 reference standards (NBS-28, NBS-30) were run to check accuracy and precision.

191 Results are reported in $\delta^{18} \mathrm{O}$ notation relative to the Vienna Standard Mean Ocean

192 Water (V-SMOW) standard, using a $\delta^{18} \mathrm{O}$ value of $9.6 \%$ for NBS - 28 (quartz) for the

193 mass spectrometer calibration. Long-term reproducibility for repeated determination

194 of reference samples was better than $\pm 0.2 \%$ o $(1 \sigma)$.

$195 \mathrm{D} / \mathrm{H}$ ratios were determined on a second SIRA-II mass spectrometer, on $\mathrm{H}_{2}$ gas

196 obtained by reduction over hot depleted-U of the water released by induction heating

197 of samples, using a vacuum line (Bigeleisen et al. 1952), following the procedures

198 described by Godfrey (1962), with modifications (Jenkin, 1988). Samples were

199 loaded into degassed platinum crucibles that were placed in quartz reaction tubes and

200 heated under vacuum to $125^{\circ} \mathrm{C}$ overnight to remove any adsorbed $\mathrm{H}_{2} \mathrm{O}$. The yield of 
201 evolved gas was used to determine the amount of structural water contained in the

202 sample. Results are reported in $\delta \mathrm{D}$ notation relative to the V-SMOW standard, using

203 a $\delta \mathrm{D}=-66.7 \%$ for NBS-30 (biotite) for the mass spectrometer calibration. Long-

204 term reproducibility for repeated determination of reference samples was better than

$205 \pm 2 \%$ ( $1 \sigma)$. The fractional extraction and purification of fluids (liquid, gas) from

206 glass inclusions was performed by means of a step-heating device.

\subsection{X-ray micro-Computed Tomography (micro-CT) and Scanning Electron}

Microscope (SEM)

210 Samples were imaged by using two different microtomographs; a ScanXmate-

211 D180RSS270 (Comscantecno Co., Ltd.) at Tohoku University, and an Argus

212 (SUINSA Medical Systems) at the University of Salamanca (USal), to characterize

213 the 3D morphology, distribution and volume of bubbles within dacites during ascent

214 from c. 19 to $13 \mathrm{~km}$ depth. The tomographic scans were performed at $150 \mathrm{kV}$ and

$215110 \mu \mathrm{A}$. The source-to-detector distance was $670.094 \mathrm{~mm}$, while the sample-to-

216 detector distance was $39.747-63.403 \mathrm{~mm}$. Each sample was set on a rotation stage,

217 and transmission images were obtained for each $0.18^{\circ}$ of rotation, to a total of 2000

218 images. The isotropic pixel edge sizes ranged between 7.53 and $12 \mu \mathrm{m}$.

219 Three-dimensional (3D) analyses were reconstructed from the transmission

220 images by using an original software package called "Slice" (Okumura et al., 2008).

221 A representative volume for each sample was selected in order to avoid exposed

222 surfaces and to remove fractures due to sample preparation (see Table 1).

223 The SEM images were segmented to separate bubbles from glass and crystals.

224 The segmentation consists in the choice of a threshold, in order to obtain binary

225 images where the vesicles are isolated from the dacite. For the binarization, we 
226 translated CT values to 8 bit values and then made binary images using a threshold

227 value in 8 bit images, which allowed us to separate the vesicles from the dacite.

228 Next crystals in the magma need to be individualized from its glassy matrix. To

229 this end, a pre-segmentation step is usually required to increase the contrast between

230 different phases and to remove background noise, as both crystals and glassy matrix

231 in a sample may have similar X-ray attenuation coefficients (e.g., Zandomeneghi et

232 al., 2010; Voltolini et al., 2011). However, for most of the samples considered (HY-

233 14-10, HY-14-8 and HY-14-2), the contrast between crystals and their embedding

234 matrix was enough as not to require segmentation. Only sample HY-14-9 required

235 application of a bilateral filter (Tomasi and Manduchi, 1998) by using "ImageJ"

236 software (Abramoff et al., 2004), in order to better distinguish the crystals from their

237 glassy matrix, reducing the noise and potential artifacts while preserving edges and

238 the shape of the objects. This type of image processing separated bubbles, glass and

239 crystals, and allowed us to calculate bubble abundances and dacite porosity. We then

240 calculated the bubble number density (BND = number of bubbles / volume of glassy

241 groundmass) and bubble size distribution (BSD) (Cashman and Mangan, 1994;

242 Hurwitz and Navon, 1994; Mangan and Cashman, 1996; Gardner et al., 1999; Larsen

243 and Gardner, 2000; Blower et al., 2001, 2002; Toramaru, 2006; Bai et al., 2008;

244 Polacci et al, 2008, 2009; Baker et al. 2012; LaRue et al., 2013; Masotta et al., 2014)

245 ( see Table 1b). BSD and BND can be used to discern between single or multiple

246 nucleation events during the magma ascent (Bai et al., 2008).

247 In addition, we utilized SEM visual analysis (secondary electron detector) at the

248 Centro de Láseres Pulsados (USal) to check for the presence of bubbles below the

249 detection limit of micro-CT. The SEM used an Extra High Tension of $10.94 \mathrm{kV}$,

250 Working Distance of 6-17 mm, and Irrigating Probe at $32 \mathrm{pA}$. 


\section{Results: Stable Isotopes, micro-CT and SEM}

253 Oxygen and hydrogen isotopic ratios in dacite were $\delta^{18} \mathrm{O}=15.4 \pm 0.2 \%$ and $\delta \mathrm{D}=-$ $25487.1 \pm 3.3 \%$ o $(1 \sigma, n=4)$, respectively. In the xenoliths, whole rock measured values 255 were marginally lighter (although this effect may be attributed to one single sample) 256 and more variable, at $\delta^{18} \mathrm{O}=15.3 \pm 0.6 \%$ and $\delta \mathrm{D}=-89.2 \pm 9.4 \%$ o $(1 \sigma, \mathrm{n}=4)$. When 257 mineral separation could be achieved, oxygen isotopic ratios were always higher in 258 the xenoliths than in the host dacite (see Table 2; Fig. 2). The unusually high values of the oxygen isotopic ratios measured are in line with values reported by Benito et

260 al. (1999) for the NVP in general and El Hoyazo in particular.

\subsection{Shallow samples (i.e., at $13 \mathrm{~km}$ depth)}

263 Of the samples available, HY-14-10 corresponds to the shallowest levels.

264 Measured values for the dacite were $\delta \mathrm{D}=-89.2 \%$ and $\delta^{18} \mathrm{O}=15.1 \%$, while the 265 crustal xenoliths gave $\delta \mathrm{D}=-85.5 \%$ and $\delta^{18} \mathrm{O}=14.5 \%$ (Table 2 ). The estimated 266 porosity in the dacites is $6.4 \%$ and its BND is $235 \mathrm{~mm}^{-3}$ (Table 1; Fig. 3). BSD 267 results indicate a significantly higher number of small size bubbles than those of 268 large size (Fig. 4). SEM images reveal local orientation trends of the bubbles in the 269 dacites (Fig. 3f), as well as irregular geometries (e.g., Fig. 5a, c).

\subsection{Deep samples (i.e., at $19 \mathrm{~km}$ depth)}

272 Sample HY-14-9 comes from the deepest part of the dacitic dyke (Fig. 3, a,b) $\delta D$ 273 and $\delta^{18} \mathrm{O}$ values are -88.5 and 15.1 , respectively. The crustal xenoliths within this 274 sample gave $\delta \mathrm{D}=-102.8 \%$ and $\delta^{18} \mathrm{O}=15.7 \%$ (Table 2 ). In the dacite, the porosity 275 is $1.7 \%$ and its BND is $763 \mathrm{~mm}^{-3}$ (Table 1; Fig. 3). BSD estimates reveal that the 
276 number of bubbles of small size is higher than those of larger size (Fig. 4). SEM

277 images indicate that deep dacites often show elongated bubble geometries (e.g., Fig.

$2785 \mathrm{e}, \mathrm{g})$.

279 Simple first order estimates of bubble growth according to results shown in Fig. 4, 280 i.e., how much does a bubble varies (in terms of size) as pressure drops, when other

281 key parameters are in equilibrium (namely e.g., the amount of gas species degassing 282 into the bubble from the surrounding silicate liquid per unit time, itself dependent on 283 the initial volatile composition of the melt, its viscosity and surface tension, and

284 kinetics) hints at an average bubble size enlargement of up to $13 \mathrm{~mm}^{3} / \mathrm{Kbar}$.

286 4. Discussion

287 4.1. Dacite depths: Coeval quenching at the contact with crustal xenoliths

288 Phase diagram modeling (Álvarez-Valero and Waters, 2010) and numerical

289 simulations (Álvarez-Valero et al., 2015; Pla and Álvarez-Valero, 2015) for El

290 Hoyazo volcano, indicate that the magma ascended from c. 19 to $13 \mathrm{~km}$ depth in the

291 range of minutes to hours. Measured isotopic ratios are consistent with this scenario:

292 average $\delta^{18} \mathrm{O}$ and $\delta \mathrm{D}$ are indistinguishable from each other in dacites and their

293 xenoliths (Fig. 2, Table 2). Equilibrium / disequilibrium relations established at depth

294 were preserved during rapid ascent and quenching of the magma, that had no time to

295 reset isotopic ratios, and inherited, therefore, $\delta^{18} \mathrm{O}$ and $\delta \mathrm{D}$ values acquired at high

296 temperature (i.e., c. $850^{\circ} \mathrm{C}$ ) in the magma source region. If anything, there is hint for

297 heavier $\delta \mathrm{D}$ values and lower water contents in shallower samples (HY-14-10)

298 relative to deep ones (HY-14-9), present in both dacites and their xenoliths.

299 The $\delta \mathrm{D}-\mathrm{H}_{2} \mathrm{O}$ isotope systems allow us to determine whether or not gas is able to

300 decouple from melt via open-system degassing (e.g., Taylor et al., 1983; Newman et 
301 al., 1988; Castro et al., 2014). In other words, the isotopic change in a perfectly

302 closed (and theoretical) system exhibits a linear trend by following the mass balance 303 equation of Taylor et al. (1983) where $\delta \mathrm{D}$ decreases moderately for a relatively large

304 decrease in the bulk $\mathrm{H}_{2} \mathrm{O}$ in solution in the magma. Comparing the deepest (HY-14-

3059 9) with the shallowest (HY-14-10) sample, our results show that $\delta \mathrm{D}$ actually

306 increases from bottom to top, at the time that $\mathrm{H}_{2} \mathrm{O}$ contents become similar or

307 slightly lower. If the El Hoyazo system behaved as an open system, different

308 opposite situations would be expected (i.e., either open system water degassing or

309 hydration should result in lower $\delta$ D; Taylor et al., 1983; Newman et al., 1988). This

310 indicates that the magmatic system below El Hoyazo did not detect significant

311 additions of external volatiles during magma ascent, nor experienced significant

312 fluxes of volatiles from the surrounding crust.

313 Local microtextures in the dacites are similar to those in the xenoliths, involving

314 similar mineral assemblages, namely biotite-hercynite-cordierite-melt and garnet-

315 biotite-cordierite-melt (Fig. 1c, d, e). This suggests that the dacites were also partly

316 quenched at those particular depths, i.e., 19 and $13 \mathrm{Km}$ (see also Newmann et al.,

317 1988). Xenolith textures were the result of an anatectic episode, that produced large

318 amounts of melt that escaped from the pelitic country rocks (as described by Zeck,

319 1970), resulting in migmatization (and quenching) (Álvarez-Valero and Waters,

320 2010). This event was prior and independent of the transient melting event that

321 rapidly erupted the dacites, transporting all xenolith types to the surface. Therefore

322 we inferred the provenance depth of the dacites, and in turn their measured variation

323 of porosity from 1.7 to $6.4 \%$ between 19 and $13 \mathrm{~km}$ depth (Table 1 ), from the

324 pressure at which their hosted metapelitic xenoliths equilibrated. We state that,

325 otherwise, during the ascent from 19 to $13 \mathrm{~km}$, the different magmatic and porosity 
326 microtextures may show evidence of magma fragmentation (e.g. Eichelberger,

327 1995), or been homogenized during their ascent from $13 \mathrm{~km}$ depth to the surface.

328 This agrees with recent experimental constraints (e.g., Brugger and Hammer, 2010;

329 Cichy et al., 2011), which demonstrated that changes in mineral assemblage, crystal

330 abundance, variation in mineral compositions and texture are related to isothermal

331 magma ascent and decompression rates.

332 Therefore given that the exposed dacites are not homogenized in terms of porosity

333 in El Hoyazo, we speculate that rapid magma ascent may also have inhibited bubble

334 and crystal nucleation above $13 \mathrm{~km}$ (e.g. Mangan and Sisson, 2000; Lloyd et al.,

335 2014). In other words, a rapid ascent above $13 \mathrm{~km}$ depth may favour a delay in the

336 nucleation process.

\subsection{Correlation between porosity and depth}

339 The volume of bubbles in an erupted volcanic rock may not necessarily reflect the

340 P-T conditions at which the bubbles formed in the dike, since processes such as

341 outgassing and late-stage crystallization may occur during magma ascent. These

342 processes can promote irregular bubble shapes between the microlites (Fig. 5a) due

343 to the collapse of the bubble. This collapse is promoted by the relaxation timescale

344 that depends on the surface tension of the bubble as well as the melt viscosity. It is

345 widely accepted that when a melt supersaturated with volatiles is depressurized,

346 small clusters of gas molecules nucleate and grow through volatile diffusion in the

347 melt (e.g., Toramaru, 1995; Proussevitch and Sahagian 1996, 1998). We focus on

348 vesicle growth at depth (Fig. 3), not on the initial nucleation process, which is

349 beyond the scope of this contribution. The growth of gas bubbles mainly requires

350 volatile diffusion from the melt into pre-existing bubbles, as growth is kinetically 
351 favoured over nucleation when the degree of supersaturation is low enough as not to

352 achieve the necessary nucleation pressure. This also depends on the volatile

353 composition of the melt, its viscosity and surface tension (e.g., Mangan and Sisson,

354 2005; Masotta et al., 2014). Another important driver of bubble growth is the

355 mechanical expansion due to decreasing ambient pressure (e.g., Proussevitch et al.

356 1993; Sparks et al. 1994; Huber et al. 2014).

357 The consistency of groundmass and crystal volumes between 19 and $13 \mathrm{~km}$ depth

358 supports that little late-stage crystallization occurred (Table 1, Figs. 3 5), whereas the

359 local orientation trends of the bubbles (Fig. 3e) may be related to the stress

360 conditions at the dike's wall, that were not homogenized at the shallow vent depths.

361 Along the $6 \mathrm{~km}$-dike dacites show similar water contents and microtextures,

362 indicating uniform conditions during magma ascent and degassing (Martel et al.,

363 2000). In addition, the relationship between porosity (Table 1) and dissolved water

364 match the quantitative trends in the multicomponent liquid-gas equilibrium in a

365 silicic system of Papale et al. (2006). Outgassing during rapid feeder dike

366 emplacement is nearly constant at low porosity (Takeuchi et al., 2009), likely due to

367 the opening and healing of fractures on short timescales, followed by densification of

368 the dome dacites, along the shallow parts of the conduits (e.g., Okumura et al.,

$3692010)$.

370 The presence of crystals (c. $25 \%$ of mainly plagioclase, biotite and hornblende;

371 Figs. 3, 5) may have reduced the activation energy for the nucleation of bubbles, and

372 induced nucleation at $13 \mathrm{~km}$ that increased the number of bubbles (confirmed by

373 BND and BSD, Table 1 and Fig. 4). Since crystals are normally present at magma

374 storage conditions in natural magmatic systems, heterogeneous nucleation is often

375 expected (e.g., Mangan et al. 2004), especially in the studied case, where the 
376 interstitial melt contains crystals and is not supersaturated (e.g., Hurwitz and Navon

377 1994). Furthermore, the occurence of bubbles is not systematically related to any

378 particular crystal distribution or type (Fig. 3). Therefore, bubbles growth within the

379 El Hoyazo volcano was related to heterogeneous nucleation.

$380 \quad$ Our results indicate that (i) the porosity in the dacites increases upward from 1.7

381 to $6.4 \%$ (i.e., from 19 to $13 \mathrm{~km}$ depth, respectively), thus yielding a porosity opening

382 rate of $0.78 \% / \mathrm{km}$ (see also Table 1), and an average bubble growth of up to 13

$383 \mathrm{~mm}^{3} / \mathrm{Kbar}$ (see also Fig. 4); (ii) BND values of 763 and $235 \mathrm{~mm}^{-3}$ for the deep and

384 shallow samples, respectively, are in line with both bubble nucleation clustering

385 around grain boundaries (microlite, xenocryst, xenolith) at higher depths (Figs. 3, 4,

386 5), as well as higher coalescense at $13 \mathrm{~km}$ than at $19 \mathrm{~km}$ depth. Deep bubble

387 formation contributes to crustal overpressure (e.g., Malfait et al., 2014) and to the

388 lubrication of crystal-rich magmas (e.g., Pistone et al., 2013).

389 Therefore, the presence of small amount of bubbles between 19 and $13 \mathrm{~km}$ allows

390 a better understanding of the rapid magma ascent rates obtained from numerical

391 simulations by Álvarez-Valero et al. (2015) and Pla and Álvarez-Valero (2015).

392 Hence, deep bubble formation must be included in evaluations of silicic magma

393 eruptivity (e.g., Takeuchi, 2004; Gottsmann et al., 2009).

\section{CONCLUDING REMARKS}

396 - Bubble nucleation and volume in the deep magma dike increase during ascent-

397 driven decompression at a lower rate and to a lower extent than has been described 398 for shallow vents.

399 - Rapidly ascending magma at El Hoyazo volcano experiences negligible late-

400 stage crystallization and bubble nucleation at depths above $13 \mathrm{~km}$ below the surface. 
$401 \quad$ - The present porosity rate of $0.78 \% / \mathrm{km}$ may be used in silicic subvolcanic

402 systems as an approximation in models and experiments for a better understanding of

403 deep bubble formation, and if necessary, to accurately evaluate magma eruptibility.

404 - Silicic lava domes hosting crustal xenoliths are extraordinary scenarios to study

405 different bubble snapshots along their evolution during ascent in a deep dike. We

406 provide evidence of how bubbles may behave within the deep silicic dike beneath El

407 Hoyazo. Our results can be used as a proxy for crystallization and bubble formation

408 beneath contemporary volcanoes, and help improving the general knowledge of the

409 vesiculation process at varying depths beneath active volcanoes.

\section{Acknowledgements}

413 This research was supported by the D. Samuel Solórzano Foundation (University of

414 Salamanca - project FS/5-2012) and Programa Propio I (Usal-2014) through A.M.A-

415 V, who also thanks the assistance of the Ramón y Cajal research program (RYC-

416 2011-07584), and the facilities at the Centro de Láseres Pulsados (CLPU - Nucleus -

417 USal). M.D. acknowledges the funded stay at the University of Salamanca in 2014

418 by the MISTI program (Massachusetts Institute of Technology [MIT] International

419 Science and Technology Initiatives). We also thank two anonymous reviewers for

420 their in-depth and constructive comments and suggestions that notably helped to

421 improve this contribution, as well as the careful editorial handling by Nelson Eby.

\section{References}

424 Abràmoff, M.D., Magalhães, P.J., Ram, S.J., 2004. Image processing with ImageJ.

425 Biophotonics international, 11, 36-42. 
426 Álvarez-Valero, A.M., Kriegsman, L.M., 2007. Crustal thinning and mafic

427 underplating beneath the Neogene Volcanic Province (Betic Cordillera, SE 428 Spain): evidence from crustal xenoliths. Terra Nova 19, 266-271.

429 Álvarez-Valero, A.M., Waters, D.J., 2010. Partially melted xenoliths as a window 430 into sub-volcanic processes: evidence from the Neogene magmatic event of the 431 Betic Cordillera, SE Spain. Journal of Petrology 51, 973-991.

432 Álvarez-Valero, A.M., Pla, F., Kriegsman, L.M., Geyer, A., Herrero, H., 2015.

433 Observing silicic magma transport in dikes at depths of $8-19 \mathrm{~km}$ : evidences from $434 \quad$ crustal xenoliths and numerical modelling. Journal of Volcanology and 435 Geothermal Research 296, 69-79.

436 Bai, L., Baker, D.R., Rivers, M., 2008. Experimental study of vesicle growth in 437 Stromboli basalt melts at 1 atm. Earth and Planetary Science Letters 267, 533$438 \quad 547$.

439 Baker, D.R., Mancini, L., Polacci, M., Higgins, M.D., Gualda, G.A.R., Hill, R.J., 440 Rivers, M.J., 2012. An introduction to the application of X-ray microtomography 441 to the three-dimensional study of igneous rocks. Lithos, 148, 262-276.

442 Baker, D.R., Brun, F., O'Shaughnessy, C., Mancini, L., Fife, J.L., and Rivers, M. 443 (2012b) A four-dimensional X-ray tomographic microscopy study of bubble 444 growth in basaltic foam. Nature Communications, 3, 1135.

445 Benito, R., López-Ruiz, J., Cebriá, J.M., Hertogen, J., Doblas, M., Oyarzun R.,

446 Demaiffe D., 1999. Sr and O isotope constraints on source and crustal

447 contamination in the high-K calc-alkaline and shoshonitic Neogene volcanic rocks $448 \quad$ of SE Spain. Lithos 46, 773-802.

449 Bigeleisen, J., Perlman, M.L., Prosser, H.C., 1952. Conversion of hydrogenic 450 materials to hydrogen for isotopic analysis. Anal Chem 24, 1536-1537. 
451 Blower, J.D., Keating, J.P., Mader, H.M., Phillips, J.C., 2001. Inferring volcanic

452 degassing processes from vesicle size distributions. Geophysical Research Letters $45328,347-350$.

454 Blower, J.D., Keating, J.P., Mader, H.M., Phillips, J.C., 2002. The evolution of 455 bubble size distributions in volcanic eruptions. Journal of Volcanology and 456 Geothermal Research 120, 1-23.

457 Borthwick, J., Harmon, R.S., 1982. A note regarding $\mathrm{ClF}_{3}$ as an alternative to BrF5 458 for oxygen isotope analysis. Geochimica et Cosmochimica Acta 46, 1665-1668.

459 Brugger, C.R., Hammer, J.E., 2010. Crystallization kinetics in continuous

460 decompression experiments: implications for interpreting natural magma ascent

461 processes. Journal of Petrology 51, 1941-1965.

462 Cashman, K.V., Mangan, M.T., 1994. Physical aspects of magmatic degassing I I.

463 Constraints on vesiculation processes from textural studies of eruptive products, $464 \quad$ Reviews in Mineralogy, 30, 447-478.

465 Castro, J.M., Bindeman, I.N., Tuffen, H., Schipper, C.I., 2014. Explosive origin of 466 silicic lava: Textural and $\delta \mathrm{D}-\mathrm{H}_{2} \mathrm{O}$ evidence for pyroclastic degassing during 467 rhyolite effusion. Earth and Planetary Science Letters 405, 52-61.

468 Cesare, B., Salvioli Mariani, E., Venturelli, G., 1997. Crustal anatexis and melt 469 extraction during deformation in the restitic enclaves at El Joyazo (SE Spain). $470 \quad$ Mineralogical Magazine 67, 15-27.

471 Clayton, R.N., Mayeda, T.K., 1963. The use of bromine pentafluoride in the 472 extraction of oxygen from oxides and silicates for isotopic analysis. Geochimica 473 et Cosmochimica Acta 27, 43-52.

474 Costa A., Melnik O., Sparks R.S.J., Voight, B., 2007. Control of magma flow in 475 dykes on cyclic lava dome extrusion. Geophysical Research Letters 34, L02303. 
476 Costa A., Sparks R.S.J., Macedonio G., Melnik O., 2009. Effects of wall-rock

477 elasticity on magma flow in dykes during explosive eruptions. Earth and

$478 \quad$ Planetary Science Letters 288, 455-462.

479 Duggen, S., Hoernle, K., van den Bogaard, P., Harris, C., 2004. Magmatic evolution

480 of the Alboran Region: the role of subduction in forming the western

481 Mediterranean and causing the Messinian Salinity Crisis. Earth and Planetary

$482 \quad$ Science Letters 218, 91-108.

483 Eichelberger, J.C., Carrigan, C.R., Westrich, H.R., Price, R.H., 1986. Non-explosive

$484 \quad$ silicic volcanism. Nature 323, 598-602.

485 Gardner, J.E., Hilton, M., Carroll, M.R., 1999. Experimental constraints on

486 degassing of magma: isothermal bubble growth during continuous decompression

487 from high pressure. Earth and Planetary Science Letters 168:201-218

488 Godfrey, J.D., 1962. The deuterium content of hydrous minerals from the east-

489 central Sierra Nevada and Yosemite National Park. Geochim Cosmochim Acta

$490 \quad 26,1215-1245$.

491 Gonnermann, H.M., Manga, M., 2007. The Fluid Mechanics Inside a Volcano.

492 Annual Review of Fluid Mechanics 39, 321-56.

493 Gottsmann, J., Lavallée, Y., Martí, J., Aguirre-Díaz, G., 2009. Magma-tectonic

494 interaction and the eruption of silicic batholiths. Earth and Planetary Science

$495 \quad$ Letters 284, 426-434.

496 Gualda, G.A.R., Anderson, A.T., 2007. Magnetite scavenging and the buoyancy of

497 bubbles in magmas. Part 1: discovery of a pre-eruptive bubble in Bishop rhyolite.

498 Contributions to Mineralogy and Petrology 153, 733-742. 
499 Gualda, G.A.R., Rivers, M., 2006. Quantitative 3D petrography using X-ray

500 tomography: application to Bishop Tuff pumice clasts. Journal of Volcanology

501 and Geothermal Research 154, 48-62.

502 Hurwitz, S., Navon, O., 1994. Bubble nucleation in rhyolitic melts: ex- periments at

503 high pressure, temperature, and water content. Earth and Planetary Science Letters

$504 \quad 22,267-280$.

505 Jaupart, C., Allègre, C.J., 1991. Gas content, eruption rate and instabilities of

506 eruption regime in silicic volcanoes. Earth and Planetary Science Letters 102,

$507 \quad 413-429$.

508 Jenkin, G.R.T., 1988. Stable isotope studies in Caledonides of SW Connemara,

509 Ireland. PhD thesis, Univ. Glasgow, UK.

510 Klug, C., Cashman, K.V., 1996. Permeability development in vesiculating magmas:

511 implications for fragmentation. Bulletin of Volcanology 58, 87-100.

512 LaRue, A., Baker, D. R., Polacci, M., Allard, P., Sodini, N., 2013. Can vesicle size

513 distributions assess eruption intensity during volcanic activity?. Solid Earth, 4,

514373.

515 Larsen, J.F., Gardner, J.E., 2000. Experimental constraints on bubble interactions in

516 rhyolite melts: implications for vesicle size distributions. Earth and Planetary

$517 \quad$ Science Letters 180, 201-214.

518 Malfait, W.J., Seifert, R., Petitgirard, S., Perrillat, J., Mezouar, M., Ota, T.,

519 Nakamura, E., Lerch, P., Sanchez-Valle, C., 2014. Supervolcano eruptions driven

520 by melt buoyancy in large silicic magma chambers. Nature Geoscience 7, 122-

$521 \quad 125$.


522 Mangan, M.T., Cashman, K.V., 1996. The structure of basaltic scoria and reticulite

523 and inferences for vesiculation, foam formation, and fragmentation in lava

524 fountains. Journal of Volcanology and Geothermal Research, 73, 1-18.

525 Martel, C., Bourdier, J.L., Pichavant, M., Traineau, H., 2000. Textures, water content

526 and degassing of silicic andesites from recent plinian and dome-forming eruptions

527 at Mount Pele.e volcano (Martinique, Lesser Antilles arc). Journal of Volcanology

528 and Geothermal Research 96, 191-206.

529 Masotta, M., Ni, H., Keppler, H., 2014. In situ observations of bubble growth in

530 basaltic, andesitic and rhyodacitic melts. Contributions to Mineralogy and

531 Petrology, 167, 1-14.

532 Newman, S., Epstein, S., Stolper, E., 1988. Water, carbon dioxide, and hydrogen iso-

533 topes in glasses from the ca. 1340 A.D. eruption of the Mono Craters, California:

534 constraints on degassing phenomena and initial volatile content. Journal of

$535 \quad$ Volcanology and Geothermal Research 35, 75-96.

536 Okumura, S., Nakamura, M., Takeuchi, S., Tsuchiyama, A., Nakano, T., Uesugi, K.,

537 2009. Magma deformation may induce non-explosive volcanism via degassing

538 through bubble networks. Earth and Planetary Science Letters 281, 267-274.

539 Okumura, S., Nakamura, M., Uesugi, K., Nakano, T., Fujioka, T., 2013. Coupled

540 effect of magma degassing and rheology on silicic volcanism. Earth and Planetary

$541 \quad$ Science Letters 362, 163-170.

542 Okumura, S., Nakamura, M., Tsuchiyama, A., Nakano, T., Uesugi, K., 2008.

543 Evolution of bubble microstructure in sheared rhyolite: formation of a channel-

$544 \quad$ like bubble network. Journal of Geophysical Research 113, B07208. 
545 O'Neill, J.R., 1986. Theoretical and Experimental Aspects of Isotopic Fractionation.

546 In: Stable Isotopes in High Temperature Geological Processes, MSA (J.W.

547 Valley, H.P. Taylor, Jr., and J.R. O'Neil, editors), v. 16, p. 1-40.

548 Papale, P., Moretti, R., Barbato, D., 2006. The compositional dependence of the

549 saturation surface of $\mathrm{H}_{2} \mathrm{O}+\mathrm{CO}_{2}$ fluids in silicate melts. Chemical Geology 229,

$550 \quad 78-95$.

551 Pistone, M., Caricchi, L., Ulmer, P., Reusser, E., Ardia, P., 2013. Rheology of

552 volatile bearing crystal mushes: mobilization vs. viscous death. Chemical

$553 \quad$ Geology 345, 16-39.

554 Pla, F., Álvarez-Valero, A.M., 2015. Biot number constraints on the sub-volcanic

555 crust-magma thermal regime: an integrating approach of numerical modelling and

556 petrology. In: Caricchi, L., Blundy, J.D. (Eds.), Chemical, Physical and Temporal

557 Evolution of Magmatic Systems. Geological Society, London, Special

$558 \quad$ Publications, 422, 207-216.

559 Polacci, M., Baker, D. R., Bai, L., Mancini, L., 2008. Large vesicles record pathways

560 of degassing in basaltic magmas. Bulletin of Volcanology, 70, 1023-1029.

561 Polacci, M., Baker, D. R., Mancini, L., Favretto, S., Hill, R. J., 2009. Vesiculation in

562 magmas from Stromboli and implications for normal Strombolian activity and

563 paroxysmal explosions in basaltic systems. Journal of Geophysical Research, B1,

564114.

565 Polacci, M., Baker, D.R., Mancini, L., Tromba, G., and Zanini, F., 2006, Three-

566 dimensional investigation of volcanic textures by X-ray microtomography and

567 implications for conduit processes. Geophysical Research Letters 33, L13312.

568 Sharp, Z.D., 1990. A laser-based microanalytical method for in situ determination of

569 oxygen isotope ratios of silicates and oxides. Geochimica et Cosmochimica Acta 
571 Takeuchi, S., 2004. Precursory dike propagation control of viscous magma eruptions. $572 \quad$ Geology 32, 1001-1004.

573 Takeuchi, S., Tomiya, A., Shinohara, H., 2009. Degassing conditions for permeable 574 silicic magmas: implications from decompression experiments with constant rates. $575 \quad$ Earth and Planetary Science Letters 283, 101-110.

576 Taylor, B.E., Eichelberger, J.C., Westrich, H.R., 1983. Hydrogen isotopic evidence 577 of rhyolitic magma degassing during shallow intrusion and eruption. Nature 306, $578 \quad 541-545$.

579 Tomasi C., Manduchi, R., 1998. Bilateral Filtering for Gray and Color Images: Sixth 580 International Conference on Computer Vision, Bombay, India, 839-846.

581 Toramaru, A., 2006. BND (bubble number density) decompression rate meter for 582 explosive volcanic eruptions. Journal of Volcanology and Geothermal Research, $583 \quad 154(3), 303-316$.

584 Valentine, G.A., 2012. Shallow plumbing systems for small-volume basaltic

585 volcanoes, 2: Evidence from crustal xenoliths at scoria cones and maars. Journal 586 of Volcanology and Geothermal Research 223-224, 47-63.

587 Voltolini, M., Zandomeneghi, D., Mancini, L., Polacci, M., 2011. Texture analysis of

588 volcanic rock samples: Quantitative study of crystals and vesicles shape preferred 589 orientation from X-ray microtomography data. Journal of Volcanology and $590 \quad$ Geothermal Research 202, 83-95.

591 Wallace, P.J., Anderson, A.T.Jr., Davis, A.M., 1995. Quantification of preeruptive 592 exsolved gas contents in silicic magmas. Nature 377: 612-616.

593 Woods, A.W., Koyaguchi, T., 1994. Transitions between explosive and effusive 594 eruptions of silicic magmas. Nature 370, 641-644. 
595 Zandomeneghi, D., Voltolini, M., Mancini, L., Brun, F., Dreossi, D., Polacci, M.,

596 2010. Quantitative analysis of X-ray microtomography images of geomaterials:

597 Application to volcanic rocks. Geosphere 6, 793-804.

598 Zeck, H.P., 1970. An erupted migmatite from Cerro de Hoyazo, SE Spain.

599 Contributions to Mineralogy and Petrology 26, 225-246.

600

601

602

603 Figure Captions

604 Figure 1. (a) Location of El Hoyazo volcano within the NVP and map of the Betic

605 Cordillera and Rif; (b) Field aspect of a spinel-cordierite-melt (Spl-Crd-M) xenolith

606 type in the dacitic lava of this volcano. Plane-polarized light microscopy views of:

607 (c) a xenolith at c. $19 \mathrm{~km}$ depth, in contact with its host dacite, which show local

608 textures of mineral equilibria (e.g. biotite-hercynite-melt) that are also found in the

609 xenolith; (d) a dacite that show the same chemical reactions and textures as in (c) far

610 from the contact with the xenolith; (e) a xenolith at c. $13 \mathrm{~km}$ depth, in contact with

611 its host dacite, which show a typical texture in the xenoliths such as garnet xenocryst

612 with a cordierite-plagioclase-melt corona. Microstructures in the xenoliths reveal a

613 first stage of migmatization overprinted by a sequence of melt-bearing reaction

614 microstructures (see the text for details). The microstructural features in the dacites

615 enhance the possibility of partial quenching at depth.

616 Figure 2. Stable isotopes analysis of El Hoyazo dacitic magma and crustal xenoliths.

617 Dacites and their included xenoliths show negligible $\delta{ }^{18} \mathrm{O}$ fractionation between

618 them, which is typical for rapid subvolcanic decompression occurring at high 
619 temperatures (e.g., O'Neill, 1986). The $\delta$ D values differentiate the water

620 provenances of dacites and crustal xenoliths.

621 Figure 3. (a) Scheme (not to scale) of the subvolcanic system at El Hoyazo volcano.

622 Three-dimensional view of samples HY-14-9 (b) and HY-14-10 (c), which were in

623 contact with xenoliths equilibrated at c. 19 and $13 \mathrm{~km}$ depth, respectively. Glass and

624 minerals were suppressed for clarity. Bubbles are shaded dark grey (the clearer grey,

625 the higher bubbles concentration). (d) 2D example view of a single

626 microtomographic slice to highlight -in white (e) - the crystals amount vs.

627 groundmass vs. bubbles. Grt: garnet xenocryst; Pl: plagiclase; Hb: hornblende; Bt:

628 biotite. (f) view of a single tomographic slice of sample HY-14-10 to highlight the

629 bubbles orientation within the dacite.

630 Figure 4. Bubble sizes distribution (BSD) diagram in the dacites HY-14-9 and HY-

631 14-10 (see also Figs. 3, 5 and Table 1). BSD shows that at higher depth the number

632 of small size bubbles is higher than at lower depth. In the same way, BSD also

633 reveals that at shallower depth the number of bubbles is lower but of larger size than

634 at higher depth.

635 Figure 5. SEM-SEI images of the same dacites of Figure 3 revealing the existence of 636 tiny bubbles and fractures that are below the detection limit of the micro-CT, as well

637 as the high groundmass/microlites ratio that indicates a minor influence of a potential

638 late-stage vesiculation process (see Fig. 3). Bubbles in lava HY-14-10 (shallowest

639 one) show more irregular shapes and larger sizes (e.g., a, c) than in lava HY-14-9

640 (deepest dacite) with smaller bubbles and more elongated geometries (e.g., e, g). (h)

641 Current bubble after an exsolved fluid inclusion in a biotite crystal. The groundmass

642 and crystals volumes are fairly constant along the vertical studied $6 \mathrm{~km}$ section of the 
643 dike. The bubbles sizes below the detection limit of the micro-CT indicate that our

644 measurements of the total volumes are minimum.

645 Table 1. (a) Representative volumes used for porosities estimation of the dacites

646 along c. 19 and $13 \mathrm{~km}$ depth within the dike. (b) Microtextural parameters utilized

647 for quantitative analysis of BND and BSD calculations. The bubbles sizes below the

648 detection limit of the micro-CT (Fig. 5) indicate that our measurements of the total

649 volumes are minimum. (*) Álvarez-Valero and Waters, 2010; (**) Álvarez-Valero

650 and Kriegsman, 2007.

651 Table 2. Values of the stable isotopes analysis $\left(\delta^{18} \mathrm{O}, \delta \mathrm{D}\right)$ of El Hoyazo dacitic

652 magma and crustal xenoliths.

653 
Figure 1
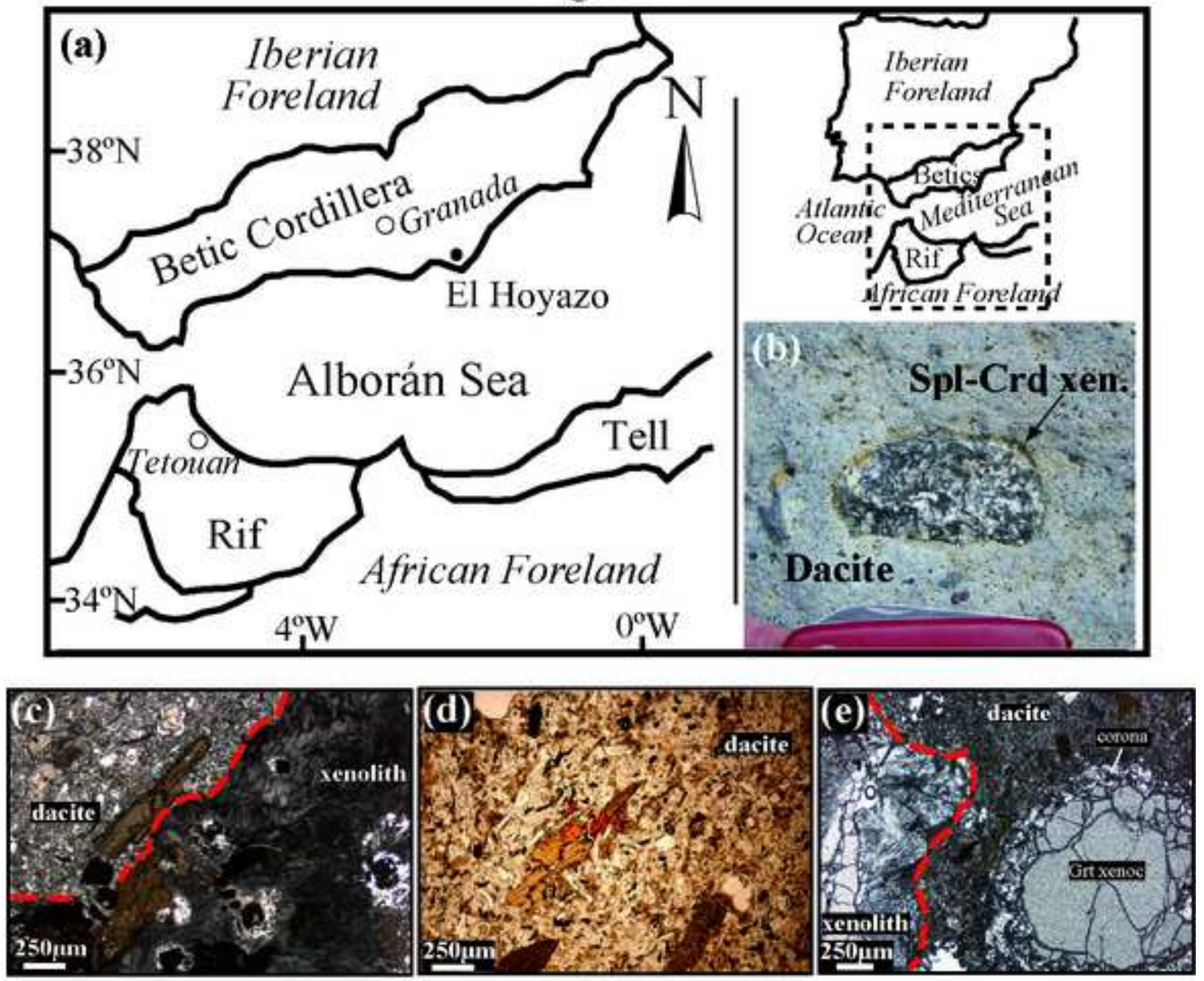
Click here to download high resolution image

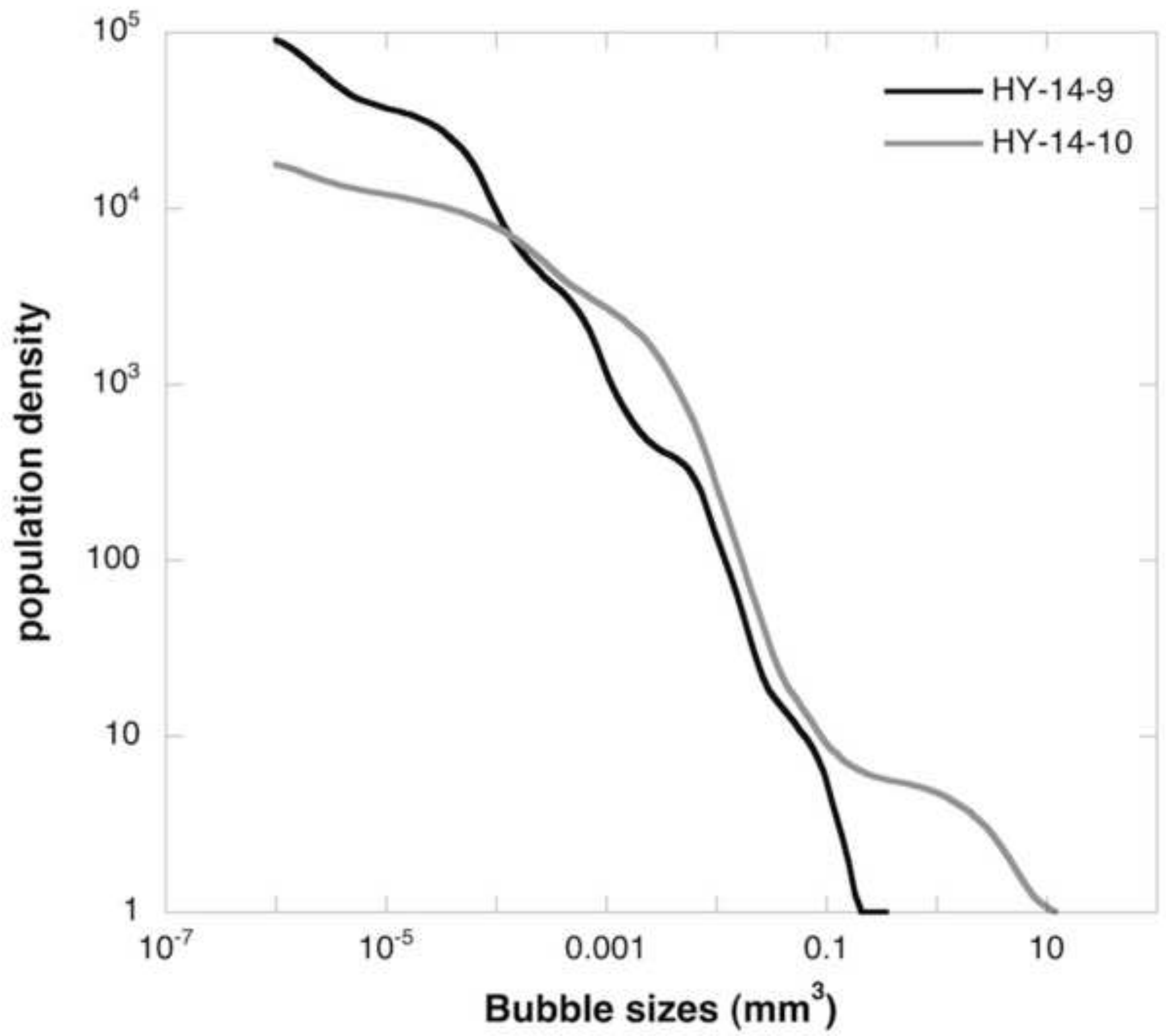


Click here to download high resolution image
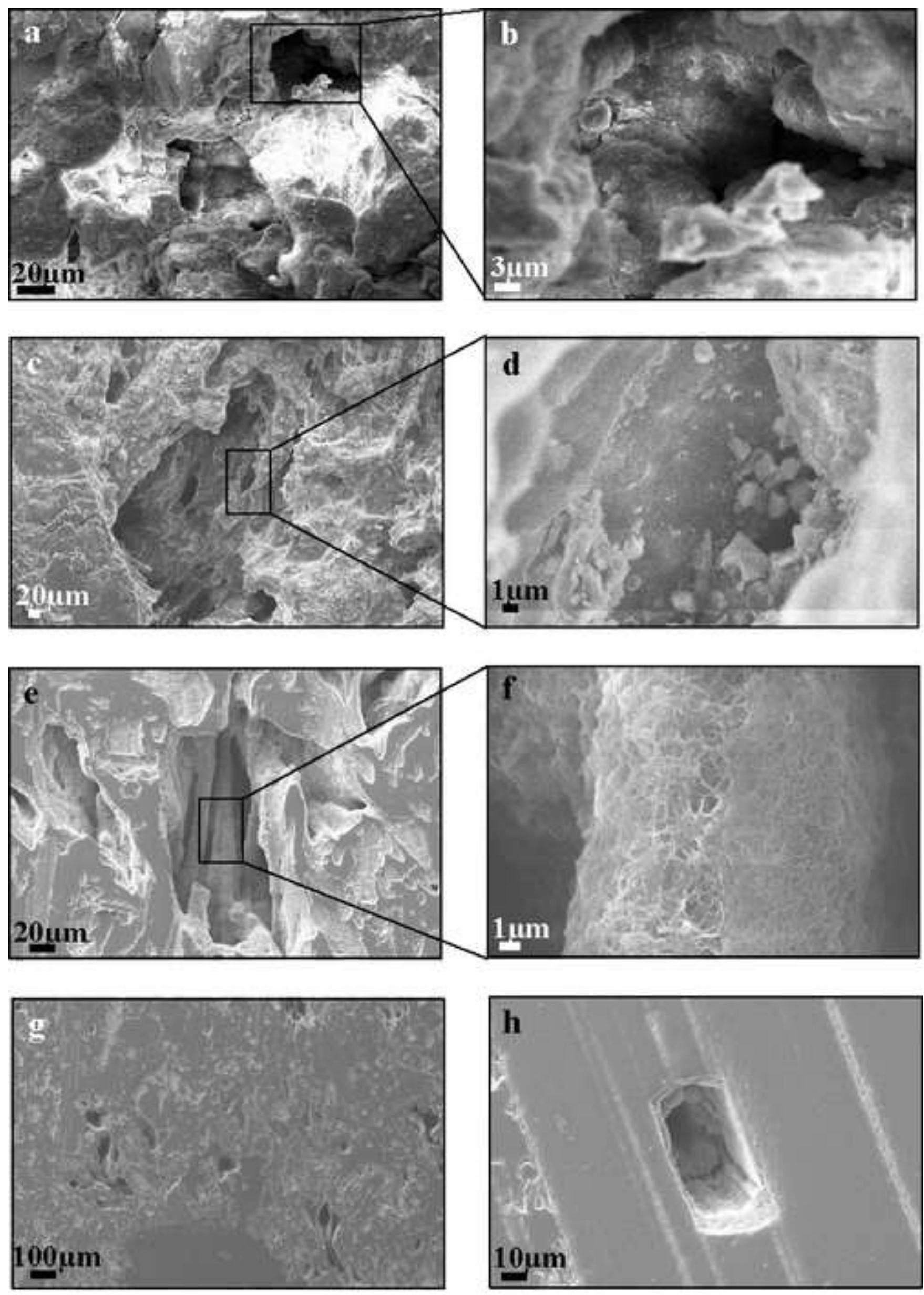
TABLE 1

\begin{tabular}{|c|c|c|c|c|c|c|c|c|}
\hline Lava Sample & $\begin{array}{l}\text { Isotropic pixel } \\
\text { edge sizes - }(\mu \mathrm{m})\end{array}$ & $\begin{array}{c}\text { Total imaged } \\
\text { volume (mm3) }\end{array}$ & $\begin{array}{l}\text { Total measured } \\
\text { volume (mm3) }\end{array}$ & $\begin{array}{l}\text { BUBBLES } \\
\text { Porosity (\%) }\end{array}$ & $\begin{array}{c}\text { BUBBLES } \\
\text { Volume (mm3) }\end{array}$ & $\begin{array}{c}\% \mathrm{H} 2 \mathrm{O}( \pm 0.1) \\
\text { calculated } \\
\text { (dacite) }\end{array}$ & $\begin{array}{c}\% \mathrm{H} 2 \mathrm{O} \text { bulk } \\
\text { dacite } \\
\text { (estimated } \\
\text { from XRF) } \\
\end{array}$ & $\begin{array}{l}\text { Xenolith peak } \mathrm{P}(\mathrm{kbar}, 2 \sigma) \\
\text { metamorphism }\end{array}$ \\
\hline HY-14-10 & 9.96 & 746 & 746 & 6.4 & 35.0 & 2.3 & \multirow{3}{*}{$3.7-4$} & $4.7 \pm 0.3$ (c. $13 \mathrm{~km} \mathrm{depth)}$ * \\
\hline HY-14-8 & 12.00 & 966 & 966 & 3.1 & 31.7 & \multirow[b]{2}{*}{ up to 4.1} & & $\begin{array}{c}5.7 \pm 0.3(5.4 \sim \text { c. } 16.2 \mathrm{~km} \text { depth }) \\
*\end{array}$ \\
\hline $\begin{array}{l}\text { HY-14-2 } \\
\text { HY-14-9 }\end{array}$ & $\begin{array}{c}12.00 \\
7.53\end{array}$ & $\begin{array}{c}1084 \\
322\end{array}$ & $\begin{array}{l}1084 \\
322\end{array}$ & $\begin{array}{l}1.7 \\
1.7\end{array}$ & $\begin{array}{l}18.2 \\
4.76\end{array}$ & & & $\begin{array}{c}5.7 \pm 0.3(6.0 \sim \text { c. } 18 \mathrm{~km} \mathrm{depth}) * \\
\quad 6.2 \pm 0.8(\text { c. } 19 \mathrm{~km} \text { depth }) * * *\end{array}$ \\
\hline Sample & $\begin{array}{l}\text { Analized volume } \\
\text { (pixel) }\end{array}$ & $\begin{array}{l}\text { Analized volume } \\
\text { (mm3) }\end{array}$ & $\mathrm{N}^{\circ}$ Bubbles & $\begin{array}{c}\text { GROUNDMASS } \\
\text { Volume (mm3) }\end{array}$ & $\begin{array}{c}\text { CRYSTALS } \\
\text { Volume (mm3) }\end{array}$ & $\begin{array}{c}\text { CRYSTALLINIT } \\
\mathrm{Y}(\%) \\
\end{array}$ & BND (mm-3) & \\
\hline HY-14-10 & $792 \times 522 \times 701$ & 286 & 43687 & 185.68 & 74.1 & 28.5 & 235 & \\
\hline HY-14-9 & $870 \times 1100 \times 700$ & 286 & 159924 & 209.64 & 71.6 & 25.4 & 763 & \\
\hline
\end{tabular}




\begin{tabular}{cccc} 
Sample & Type & $\boldsymbol{\delta}^{\mathbf{1 8}} \mathbf{O}( \pm 0.15)$ & $\boldsymbol{\delta} \mathbf{D}( \pm 1)$ \\
\hline HY-14-10 & dacite (bulk) & 15.6 & -83.6 \\
HY-14-8 & dacite (bulk) & 15.3 & -91.0 \\
HY-14-2 & dacite (bulk) & 15.5 & -85.2 \\
HY-14-9 & dacite (bulk) & 15.1 & -88.5 \\
& & & \\
HY-14-10 & xenolith (bulk) & 14.5 & -85.5 \\
HY-14-8 & xenolith (bulk) & 15.6 & -81.5 \\
HY-14-2 & xenolith (bulk) & 15.5 & -86.8 \\
HY-14-9 & xenolith (bulk) & 15.7 & -102.8 \\
& & & \\
HY-14-8 & cordierite in xenolith & 15.5 & -78.2 \\
HY-14-9 & cordierite in xenolith & 15.1 & - \\
HY-14-9 & garnet in xenolith & 14.0 & - \\
HY-14-9 & plagioclase in xenolith & 15.1 & - \\
& & & \\
HY-14-7 & garnet in dacite & 13.5 & -80.9 \\
HY-14-8 & garnet in dacite & 13.6 & - \\
HY-14-9 & garnet in dacite & 13.7 & - \\
HY-14-9 & quartz in dacite & 12.5 & -
\end{tabular}

